результатами, які видала програма: $V_{1}=0,628737$ куб.од., $V_{2}=1,04741$ куб.од., тоді $V=1,04741$ - 0,628737 =0,418673 куб.од.

Як бачимо, працювати з описаними вище програмними засобами легко, що дозволяє швидко отримати результат і за короткий час розв’язати більшу кількість задач, ніж це можна було б зробити на папері або на дошці.

Отже, можна зробити висновки: IKT можуть замінити певні традиційні засоби навчання, що використовуються для посилення наочності; використання IKT на уроках математики дозволяє активізувати пізнавальну діяльність учнів, розвивати їхнє наочнообразне та наочно-дієве мислення; при правильному використанні дозволяють підвищити ефективність навчального процесу. Використовуючи IKT на уроках математики, учитель досягає реалізації таких цілей навчання, як розвиток пізнавальних потреб, розвиток навичок та вмінь в експериментально-дослідницькій діяльності, розвиток системного мислення, формування інформаційної культури. Обсяг інформації, що міститься в мережі Internet, надає змогу підвищення ефективності самоосвіти учнів. У подальшому плануємо розглянути можливості IKT під час проведення факультативів та гурткових занять з математики.

\title{
Література
}

1. Евстегнеева А. С. Применение компьютера в курсе математики средней школы / А. С. Евстегнеева // Молодой ученый. - 2013. - № 12. - С. 1-3. 2. Мерзляк А. Г. Алгебра. 11 клас: [підруч. для загальноосвіт. навч. закладів: академ. рівень, проф. рівень] / А. Г. Мерзляк, Д. А. Номіровський, В. Б. Полонський, М. С. Якір. - Харків : Гімназія, 2011. - 431 с. 3. Ноздрачева В. П. Об использовании программы Advanced Grapher в качестве виртуальной моделирующей среды для преподавания высшей математики [Електронний ресурс]/ В. П. Ноздрачева // Электронный журнал Вопросы Интернет Образования. - Режим доступу : http://vio. uchim. info/Vio_31/cd_site/articles/art_4_1.htm 4. Слєпкань 3. I. Методика навчання математики : [підруч. для студ. мат. спеціальностей пед. навч. закладів] / 3. І. Слєпкань.Київ : Зодіак-ЕКО, 2000. - 512 с.

\section{ДОСЛІДНО-ЕКСПЕРИМЕНТАЛЬНЕ НАВЧАННЯ АНГЛОМОВНОЇ ЛІНГВОСОЦІОКУЛТУРИ УЧНІВ СТАРШОЇ ШКОЛИ}

Бронетко I. A. Дослідно-експериментальне навчання англомовної лінгвосоціокультури учнів старшої школи.

У статті окреслено етапи формування в учнів старшої школи лінгвосоціокультурної компетенції: лінгвістичний, ситуативний, інтегративно-творчий та відповідно ним різні типи вправ країнознавчої тематики.

Ключові слова: лінгвосоціокультурна компетенція, лінгвістичний, ситуативний, інтегративно-творчий етап.

Бронетко И. А. Экспериментальное обучение английской лингвосоциокультуре учеников старшей школы.

В статье разработаны этапы формирования лингвосоциокультурной компетенции: лингвистический, ситуативный, интегративно-творческий и соответствующая система упражнений со страноведческой тематикой. 
Ключевые слова: лингвосоциокультурная компетенция, лингвистический, ситуативный, интегративно-творческий этапы.

Bronetko I. A. English lingual socio-culture experimental training of high school students

This article deals with stages of formation of lingual and sociocultural competence of pupils of high school: lingual, situational, integrative creative and corresponding system of exercises with country-studying component.

Key words: lingual and sociocultural competence, lingual, situational, integrative creative stages.

Теоретико-методологічні засади навчання іноземних мов у контексті міжкультурної комунікації висвітлено в роботах таких науковців, як: І. Бім, О. Бігич, С. Боднар, Н. Бориско, Є. Верещагін, В. Воробйов, І. Зимня, В. Костомаров, О. Монтьєв, В. Маслова, Ю. Пассов, I. Рогова, В. Сафонова, О. Тарнапольський, С. Тер-Мінасова, Г. Томакін, Л. Блумфілд, Д. Браун, Ян Ван Дайк та ін. Результати досліджень стали основою для розробки методики формування іншомовної соціокультурної компетенції: в учнів загальноосвітніх шкіл засобами позакласної (О. Шиліна) і проектної (Ю. Бевзін) роботи; у процесі навчання англійського діалогічного мовлення (Ю. Кузьменко), на основі текстів-полілогів культурнокраїнознавчого характеру (Л. Головчук) у студентів немовних спеціальностей: психологічного (І. Султанова), технічного (В. Топалова), фінансово-економічного (О. Щербакова), нефілологічного (Р. Гришкова) профілів; студентів мовних спеціальностей у процесі читання публіцистичних (О. Бирюк), прагматичних (Л. Біркозаєва), художніх (Л. Рудакова, О. Профотаєва) текстів, навчання монологічного і діалогічного мовлення (А. Гордєєва), фразеології (К. Балабуха), позанавчальної діяльності (С. Шеховцова), професійної підготовки (І. Закір’янова), засобами фольклорного матеріалу (Н. Бачинська). Водночас проблема формування англомовної лінгвосоціокультурної компетенції учнів старшої школи засобами електронного підручника була поза увагою науковців.

Мета статmі - визначити етапи формування лінгвосоціокультурної компетенції учнів старшої школи.

На підставі існуючих у науковій літературі дефініцій лінгвосоціокультурної компетенції, узагальнень практичного досвіду науковців, інтеграції різних наукових підходів до розуміння сутності лінгвосоціокультурної компетенції, визначаємо поняття «англомовна лінгвосоціокультурна компетенція учнів старшої школи» як цілісну систему вмінь використовувати знання мови, країнознавчі та фонові знання про національні традиції, норми і цінності національної культури, специфіку вербальної та невербальної поведінки, яка прийнята у певній культурі, звичаї і факти країни, мова якої вивчається, лінгвокраїнознавчий мінімум словникового запасу мови, що в сукупності надає учням можливість досягати у такий спосіб повноцінної комунікації.

Формування АЛСКК учнів старшої школи здійснюємо на основі компетентнісного, особистісно-діяльнісного, комунікативного, лінгвістичного, текстоцентричного та соціокультурного підходів.

У структурі АЛСКК виокремлюємо мовну, мовленнєву, лінгвістичну, текстову, соціокультурну та країнознавчу компетенції.

Складниками мовної компетенції визначаємо фонетичну, граматичну та лексичну компетентності. До складу мовленнєвої компетенції включаємо компетенцію в аудіюванні, говорінні, читанні та письмі. Лінгвістична компетенція містить семантичні, синтаксичні, 
морфологічні, фонетичні та лексичні знання. Текстова компетенція у нашому дослідженні передбачає комплекс знань і умінь сприймати, продукувати й інтерпретувати тексти різних типів (стосовно нашого дослідження - це автентичні тексти, автентичні повідомлення, афіши, слогани, справжні літературні, образотворчі твори, газетні або літературні статті, особисті листи, анекдоти, уривки зі щоденників підлітків, реклама, кулінарні рецепти, казки, інтерв’ю, науково-популярні тексти) з навчальною метою. Соціокультурну компетентність трактуємо як комплекс соціокультурних знань, навичок та вмінь, оволодіння якими забезпечує здатність учнів розрізняти специфіку культурної та мовленнєвої поведінки носія мови, виокремлювати соціокультурний контекст в іншомовному мовленні.

Цілями формування АЛСКК учнів старшої школи є практична, освітня, розвивальна, виховна, соціокультурна. 3 урахуванням цілей навчання англійської мови в загальноосвітніх школах було виокремлено компоненти змісту навчання АЛСКК учнів старшої школи: 1) позамовний, 2) лінгвістичний, 3) соціокультурний, 4) діяльнісний. Перший передбачає сфери комунікативної діяльності, теми та ситуації. Лінгвістичний компонент складається 3 мовного та мовленнєвого матеріалу. До соціокультурного компонента змісту навчання англійської мови відносимо тексти країнознавчого та соціокультурного характеру. У структурі діяльнісного компонента визначено фонетичні, лексичні та граматичні навички; вміння у різних видах мовленнєвої діяльності: в говорінні (діалогічному і монологічному мовленні), аудіюванні, читанні і письмі.

Оптимальним для формування АЛСКК учнів старшої школи визначено раціональне поєднання дидактичних (послідовності й систематичності, активності, індивідуалізації, творчості, наочності) та методичних (комунікативності, автентичності навчального матеріалу, технічного комунікативно-інформаційного забезпечення) принципів. Найбільш ефективними методами формування АЛСКК учнів старшої школи виявлено: кейс-метод, проблемне навчання, проектні технології, комунікативно-ситуативний метод, електронний підручник.

Згідно 3 тематикою дослідження формування англомовної лінгвосоціокультурної компетенції учнів старших класів загальноосвітньої школи здійснюємо в три етапи: лінгвістичний (вивчення лексики, граматики, фонетики); ситуативний (формування діалогічного та монологічного мовлення у ситуаціях соціально-побутової та соціокультурної тематики), інтегративно-творчий (використання інформації, отриманої з автентичних текстів для формування всіх видів мовленнєвої діяльності 3 метою вживання у подальшій навчальній, соціокультурній діяльності).

Перший етап - лінгвістичний - було спрямовано на формування фонетичної, лексичної, граматичної компетенції: активізацію фонових знань учнів з теми, що вивчається, а також на нівелювання труднощів фонетичного та лексико-граматичного характеру, що далі забезпечить повну концентрацію уваги учнів старшої школи на змісті автентичних текстів.

Метою другого етапу - ситуативного - був розвиток в учнів старшої школи умінь відтворювати набутті знання в ситуаціях іншомовного спілкування в діалогічній та монологічній формах (культурознавчої та соціопобутової тематики), аудіюванні і письмі.

Третій етап - інтегративно-творчий - орієнтовано на розвиток продуктивних умінь відтворювати отриману з автентичних текстів інформацію у навчальній та соціокультурній діяльності 3 аргументацією власної точки зору щодо виникаючих проблем з опорою на знання.

Виходячи з того, що учні старших класів загальноосвітніх шкіл для формування англомовної лінгвосоціокультурної компетенції повинні навчитися читати тексти 3 
автентичних джерел, відтворювати отриману 3 них інформацію у діалогічному i монологічному мовленні, у ситуаціях соціокультурної спрямованості, метою першого етапу було оволодіння фонетичною, лексичною, граматичною компетенціями для подолання i зняття труднощів формальної сторони мовлення, які б гальмували процес навчання. Отже, першою метою лінгвістичного етапу було формування фонетичної компетенції через опанування знаннями правил нормативної вимови звуків, слів, формування навичок сприймання та нормативного озвучення ізольованих ЛО та словосполучень 3 ними, а також лінгвістичних умінь сприйняття та нормативної вимови речень 3 цими ж мовними одиницями. Фонетичні знання набувалися шляхом почергового озвучування слів, фонетичні навички формувалися шляхом прослуховування слів, що вивчалися, їх повторенням за носієм мови (програма електронного підручника в ізольованому вигляді і в словосполученнях). Якість набутих знань перевірялась шляхом диференціації і впізнання ізольованих фонетичних явищ, трансформації й підстановки фонетичних явищ, складання монологів і діалогів 3 теми заняття 3 використанням нових i засвоєних раніше фонетичних явищ.

Другою метою цього етапу було формування лексичної компетенції через надання знань сутності ізольованих ЛО, формування навичок сприйняття та відтворення цих же ЛО у словосполученнях та розвиток умінь читати речення й тексти 3 раніше вивченими ЛО. Набуття лексичних знань здійснювалося шляхом відтворення окремих ЛО рідною мовою при їх сприйнятті англійською (рецептивні знання) та англійською при їх сприйнятті рідною мовою (репродуктивні знання). Лексичні навички формувались шляхом запам'ятовування словосполучень і речень зі словами, що вивчалися, їх перекладу на рідну мову, продукування власних словосполучень і речень на основі доповнення та розширення наданих зразків, а також перекладу з іноземної на рідну і навпаки. Якість набутих знань перевірялась шляхом прямого i зворотнього перекладу окремих слів, заповнення пропусків у реченнях, знаходження відповідників, написання коротких монологів та діалогів з використанням нових мовних явищ.

Третя мета лінгвістичного етапу спрямовувала на формування граматичної компетенції через надання знань з правил граматики, формування навичок сприйняття та відтворення граматичних структур, що вивчалися. Набуття граматичних знань відбувалося шляхом відтворення окремих граматичних одиниць рідною мовою при їх сприйнятті англійською (рецептивні знання) та англійською мовою при їх сприйнятті рідною (репродуктивні знання). Формування граматичних навичок здійснювалося шляхом виділення в тексті граматичних структур, їх перекладу на рідну мову, продукування власних речень на основі доповнення та розширення наданих зразків, а також їх перекладу 3 іноземної на рідну і навпаки, структурами та лексичними одиницями, що вивчалися та їх продукування в процесі розширення, уточнення та доповнення інформації. Якість набутих знань перевірялась шляхом розпізнавання граматичних структур у реченні, перекладу речень, виконання лексико-граматичних текстів (альтернативні, перехресні, на заміну), написання коротких монологів та діалогів з використанням нових мовних явищ.

На цьому етапі значна увага приділялась зняттю лексико-граматичних труднощів при читанні, аудіюванні аутентичних текстів. Досягнення цієї мети передбачало: нормативну вимову окремих ЛО, нормативну вимову зв'язних за змістом ЛО на рівні словосполучення, речення, семантизація окремих ЛО, зв’язних за змістом лексико-граматичних одиниць на рівні словосполучення та речення.

Досягнення цілей лінгвістичного етапу сприяло здійсненню наступного - 
ситуативного етапу, який було спрямовано на розвиток в учнів старших класів загальноосвітніх шкіл умінь відтворювати набутті знання в ситуаціях соціокультурного спілкування в діалогічній та монологічній формах.

Першою метою цього етапу $є$ навчання учнів спілкуванню на базі тематичних ситуацій. Для досягнення цієї мети в учнів розвиваються рецептивні передмовленнєві вміння через: 1) читання текстів, діалогів; 2) демонстрацію прочитаного у вигляді його переказу, діалогів, що складаються учнями на основі прочитаного змісту з додаванням реплік, які не вносять зміни до змісту. Тексти з культурознавчою тематикою та діалоги з соціокультурної тематики є засобами навчання. Рівень розвитку цього вміння перевіряється за допомогою тестів на розуміння змісту прочитаного.

Для засвоєння цієї ж мети в учнів розвиваються репродуктивні передмовленнєві вміння через: 1) відтворення змісту прочитаних текстів; 2) виклад змісту тексту після аудіювання; 3) драматизацію змісту у вигляді монологів, діалогів. Це вміння розвивається 3 використанням таких засобів навчання, як: питання, що деталізують слова та словосполучення, опори 3 наочності, що розкривають зміст прочитаних і прослуханих текстів і діалогів за соціокультурною тематикою.

Розвиток продуктивних передмовленнєвих умінь відбувається через складання діалогів та монологів за змістом 3 опорою на: а) деталізуючі питання, б) ключові питання, в) деталізуючі слова і словосполучення, г) ключові слова і словосполучення, д) на візуальні опори, які поступово розкривають зміст комунікації. Уміння такого рівня розвивається за допомогою різновидів наочності. Рівень розвитку цього вміння перевіряється тестами, які визначають якість мовної та мовленнєвої підготовки учнів у створюваних ними діалогах та монологах.

Друга мета спрямована на навчання учнів усного спілкування на основі випадкових непередбачених обставин. Для досягнення цієї мети розвивається реально-мовленнєве вміння першого рівня складності. Воно складається з драматизації розмови на основі непередбаченого повідомлення, ситуації, що виникає, розмови і розвивається: 1) завдяки швидкій мовленнєвій реакції на мовленнєві стимули, що поступово ускладнюються; 2) продукування мовленнєвих стимулів, що поступово ускладнюються; 3) драматизацію переговорів, що виникають на основі різних обставин. Рівень розвитку цього вміння за допомогою тестів на адекватність мовленнєвої поведінки учасників діалогічного спілкування.

Наступне реально-мовленнєве вміння другого рівня складності реалізується через драматизацію розмови на основі повідомлення, що спонтанно виникає. Це вміння розвивається шляхом прослуховування повідомлення новини і драматизації відповідних розмов без попередньої підготовки. Рівень розвитку цього вміння оцінюється за допомогою тестів, що виявляють ступінь прояву реакції на сприйняту інформацію.

Реально-мовленнєві вміння третього рівня складності виявляються в драматизації розмови, що виникає при спонтанних побутових проблемах на соціокультурну тематику. Вміння цього рівня розвиваються шляхом драматизації полілогів на основі сюжета побутової соціокультурної проблемної ситуації. Рівень розвитку цього вміння оцінюється за допомогою тестів, що перевіряють культуру мовлення комунікантів. Досягнення цього рівня у більшості учнів констатує можливість переходу до третого етапу навчання.

Інтегровано-творчий - третій етап - мав три мети навчання: 1) навчання учнів старших класів загальноосвітніх шкіл англомовної лінгвосоціокультурної компетенції на основі розробленого спецкурсу засобами електронного підручника; 2) навчання на основі 
самостійно введеної інформації до спецкурсу.

Для досягнення першої мети навчання в учнів розвиваються: 1) рецептивноінтегративні вміння шляхом читання текстів зі спецкурсу. Контроль їх розуміння здійснюється за допомогою тестів; 2) репродуктивно-інтегровані вміння - шляхом монологічного та діалогічного відтворення змісту набутих даних. Контроль рецептивноінтегративних умінь здійснюється за допомогою тестів, що визначають адекватність реплік, відтворених учасниками полілога до змісту прочитаної інформації.

Для досягнення другої мети в учнів розвиваються: 1) аналітико-інтегровані вміння шляхом пошуку додаткової інформації у мережі Інтернет та ії систематизація. Контроль розвитку цього вміння здійснюється за допомогою тестів, що визначають смислову відповідність самостійно дібраного матеріалу з додаткових джерел тому, що вивчається.

2) трансформаційно-інтегрованих умінь шляхом уведення додаткової інформації в навчальні тексти і створення в такий спосіб, вторинних інформаційно-розширених текстів. Контроль розвитку вміння здійснюється за допомогою тестів, які визначають кількість і змістову якість додатково введеної інформації;

3) презентаційно-інтегровані вміння шляхом багаторольового відтворення змісту розроблених текстів, їх монологічного та діалогічного обговорення. Контроль розвитку даного вміння відбувається за допомогою тестів, які визначають адекватність мовленнєвої поведінки комунікантів змісту розширених текстів.

Для досягнення третьої мети навчання у студентів розвиваються: 1) інтерпретаційноінтегровані вміння шляхом відтворення розширеної інформації в особистісній інтерпретації. Контроль розвитку цього вміння здійснюється за допомогою тестів, які визначають якість і кількість самостійних суджень відносно до вивченої розширеної інформації; 2) прогнозовано-інтегровані вміння шляхом драматизації розширеної інформації 3 прогнозуванням певних обставин для поглиблення значущості його змісту. Контроль розвитку цих умінь відбувається за допомогою тестів, які визначають кількість і якість висловлених ідей щодо вдосконалення предмета, що вивчається.

На кожному з етапів ми намагалися досягнути поставлених цілей та впровадити розроблену систему вправ для формування англомовної лінгвосоціокультурної компетенції учнів старших класів загальноосвітніх шкіл, яка мала свої особливості.

Під час розробки системи вправ до електронного підручника ми послуговувались класифікацією вправ, спрямованих на формування мовної, мовленнєвої, комунікативної та соціокультурної компетенції учнів. Добираючи вправи на формування лінгвосоціокультурної компетенції старшокласників, ураховували такі чинники: 1) культурологічний; 2) тематичнозмістова єдність; 3) психологічний.

Розроблена система вправ включає репродуктивні, репродуктивно-креативні, креативні (підготовчі, вступні, тренувальні, завершальні, контрольні) вправи. Систему вправ і завдань було зорієнтовано на реалізацію усіх видів мовленнєвої діяльності: слухання як особливий вид сприймання розвиває уміння відтворювати матеріал, порівнювати країнознавчий матеріал тексту з українськими фактами, визначати в ньому головне (основну думку, тему, мікротеми), читання й говоріння вдосконалює і закріплює зазначені вміння, розвиває здатність яскраво висловлювати свою думку в діалогах та дебатах на історичну або культурологічну тему. Вправи слухово-, зорово-мовленнєві, слухово-, зорово-моторні спрямовані на вдосконалення навичок через зорове й слухове сприймання усно фіксують особливості мовлення учнів задля його подальшого продукування, створює самостійні висловлювання в полілогах. 
Окрім вправ, згрупованих за етапами експериментальної методики, старшокласникам було запропоновано вправи, що відзначаються місцем та формою проведення, тематикою, ступенем пізнавальної активності учнів, критерієм комунікативності.

Було використано такі види вправ:

1) За місцем проведення: класні вправи проводилися з метою закріплення нових знань, розвитку мовленнєвих умінь старшокласників; домашні вправи виконувалися учнями вдома після ознайомлення й усвідомлення нових мовленнєвих понять. Домашні вправи мали найчастіше творчий характер: Уявіть ситуацію: вам запропонували виступити на конференції з благоустрою нашої країни з доповіддю з теми «Якщо б у Вас був шанс побудувати краще суспільство, щоб Ви змінили». Підготуйте доповідь за такими пунктами: голова суспільства - монарх чи президент; основні закони та права людей; громадський порядок; відносини з сусідніми державами.

2) За формою проведення: усні та письмові вправи були спрямовані на вдосконалення навичок учнів сприймати і продукувати діалоги різних типів й для різних ситуацій: Складіть діалог $з$ теми «Місто 3000». Обміркуйте такі пункти: місце знаходження, типи домів, сприятливі умови проживання, розваги, джерело енергії тощо.

3) За ступенем самостійності: групові, колективні та індивідуальні вправи застосовувалися задля перевірки рівня сформованості вмінь і навичок діалогічного мовлення та їх використання в процесі мовленнєвої діяльності: а) виконання тестових вправ; б) заповнення таблиць власними прикладами; в) тлумачення країнознавчих термінів; г) створення діалогів, полілогів, дискусій тощо.

Індивідуальні вправи виконувалися самостійно й були зорієнтовані на комунікативнотворчий характер діяльності старшокласника (порівняльний аналіз країнознавчого тексту), створення власних текстів (порівняння інформації про англомовні країни 3 тексту та додаткових фактів 3 теми про Україну). Наприклад: а) проаналізуйте текст про правила поведінки у Великобританії. Зробіть листівку для свого іноземного друга як поводитися в Україні. Розділить текст на дві колонки: що можна роботи і що не треба - гарні та погані манери поведінки.

Для розвитку лінгвістичної компетенції використовуються вправи на розвиток лексичних, граматичних, фонетичних знань, умінь і навичок. На розвиток лексичних знань використовуємо презентаційні, імітаційні, перекладні вправи. При виконанні вправ увага зверталася не тільки на розуміння учнями країнознавчих текстів, їх сприймання та відтворення, але й на грамотність учнів, що передбачала вдосконалення граматичних i фонетичних знань і практичних умінь, доречне використання лінгвістичних понять, користування словниками з електронного підручника та додаткової країнознавчої інформації з інтернет-мережі.

Для розвитку граматичних і фонетичних знань старшокласникам пропонувалися вправи на текстовій основі. Для набуття фонетичних знань, розвитку фонетичних навичок пропонуються вправи на:

1) презентацію лексичної інформації в письмовій формі та її семантизація з наголосом на рідну мову; 2) написання ізольованих слів у їх транскрипційному виразі та їх усне озвучення; 3) написання слів, що вивчаються, в їх буквеному виразі на основі наданої транскрипції та їх читання; 4) розпізнавання слів за їхніми першими і останніми буквам на слух; 5) написання похідних форм від слів, що вивчаються.

Для набуття знань вживання нових граматичних одиниць в реченнях пропонуються такі методичні дії: 1) презентація граматичної інформації в граматичних структурах; 
2) читання речень-прикладів, зміст яких відповідає темі, що вивчається; 3) складання речень шляхом розташування слів в правильному порядку.

Усі ці дії виконуються за допомогою таких технічних засобів, як таблиця неправильних дієслів, картки 3 граматичними структурами. Перевіряються знання граматики, що вивчається, шляхом перекладу речень з іноземної мови на рідну та з рідної на іноземну.

Отже, окреслені нами етапи дослідно-експериментального навчання учнів старшої школи та відповідна система вправ сприяють формуванню лінгвосоціокультурної компетенції учнів старшої школи.

\section{ПЕРСПЕКТИВИ ВИКОРИСТАННЯ ХМАРНИХ ТЕХНОЛОГІЙ У НАВЧАЛЬНОМУ ПРОЦЕСІ ЗАГАЛЬНООСВІТНІХ НАВЧАЛЬНИХ ЗАКЛАДІВ УКРАЇНИ}

Вакалюк Т. А., Поліщук В. В. Перспективи використання хмарних технологій у навчальному процесі загальноосвітніх навчальних закладів України.

У статті на основі аналізу наукової літератури наведені безумовні перспективи використання хмарних технологій у загальноосвітніх навчальних закладах України. Проаналізовано перспективи використання таких хмарних сервісів, як Office 365, Google Apps, Prezi. Наведено приклади їх використання в навчальному процесі шкіл України. 3'ясовано, що хмарні технології з легкістю розв'язують проблему навчальних закладів, яка полягає в неможливості своєчасного оновлення програмного та апаратного забезпечення.

Ключові слова: новітні технології, інформаційно-комунікаційні технології, хмарні технології, хмарні сервіси, навчальний процес.

Вакалюк Т. А., Полищук В. В. Перспективы использования облачных технологий в учебном процессе общеобразовательных учебных заведений Украины.

В статье на основе анализа научной литературы приведены безусловные перспективы использования облачных технологий в общеобразовательных учебных заведениях Украины. Проанализированы перспективы использования таких облачных сервисов, как Office 365 Google Apps, Prezi. Приведены примеры их использования в учебном процессе школ Украины. Установлено, что облачные технологии с легкостью решают проблему учебных заведений, которая заключается в невозможности своевременного обновления программного и аппаратного обеспечения.

Ключевые слова: новейшие технологии, информационно-коммуникационные технологии, облачные технологии, облачные сервисы, учебный процесс.

Vakalyuk T. A., Polishchuk V. V. Prospects of cloud technologies use in the training process of comprehensive educational institutions of Ukraine.

On the basis of analysis of scientific literature the prospects of cloud technologies use in comprehensive educational institutions of Ukraine are concidered. The prospects of cloud services such as Office 365, Google Apps, Prezi are analyzed. Examples of their use in training process of comprehensive educational institutions are given. It is analysed that cloud technologies solve the problem of educational institutions to update software and hardware timely.

Key words: new technologies, information and communication technologies, cloud 